\title{
Letter to the editor: Livestock-associated meticillin- resistant Staphylococcus aureus (LA-MRSA), Austria, 2013
}

Werner Ruppitsch ${ }^{1}$, Stefanie Monschein ${ }^{1}$, Sarah Lepuschitz ${ }^{1}$, Franz Allerberger ${ }^{1}$, Burkhard Springer ${ }^{1}$

1. Institute for Medical Microbiology and Hygiene, Austrian Agency for Health and Food Safety (AGES), Graz, Austria

Correspondence: Franz Allerberger (franz.allerberger@ages.at)

Citation style for this article:

Ruppitsch Werner, Monschein Stefanie, Lepuschitz Sarah, Allerberger Franz, Springer Burkhard. Letter to the editor: Livestock-associated meticillin-resistant

Staphylococcus aureus (LA-MRSA), Austria, 2013. Euro Surveill. 2017;22(46):pii=17-00758. https://doi.org/10.2807/1560-7917.ES.2017.22.46.17-00758

To the editor: In their article titled 'Livestock-associated meticillin-resistant Staphylococcus aureus (LA-MRSA) among human MRSA isolates, European Union/ European Economic Area countries, 2013', Kinross et al. recently reported on the occurrence of LA-MRSA in humans [1]. The results were obtained by an ECDC initiated study documenting the identification of LA-MRSA (i.e. CC398 and 'other' LA-MRSA) in European Union/ European Economic Area countries (EU/EEA) countries and the MRSA subtyping capacity and availability in EU/EEA national or regional reference laboratories. ECDC National Focal Points for Antimicrobial Resistance (AMR) were invited to designate a primary and alternate contact person with expertise in molecular surveillance of MRSA for public health purposes and with access to data for the survey in their respective countries; 27 of $30 \mathrm{EU} / \mathrm{EEA}$ countries responded to this request for data.

Data for Austria was missing in the report. We, the National Reference Laboratory (NRL) for coagulase-positive staphylococci, including Staphylococcus aureus, hereby report the missing data. In 2013, 250 human $S$. aureus isolates were obtained for typing: 18 isolates (7.2\%) were of sequence type (ST)398 and belonged to five different spa types and six different cluster types (Table) [2]. Except for nine further human isolates of ST1 (spa type 127), no 'other LA-MRSA' was documented in 2013. All isolates were Panton-Valentine leukocidin (PVL)-negative.

Within Decision 2012/506/EU on case definitions for reporting communicable diseases, reporting of MRSA in the EU/EEA is included as a 'Special health issue' of 'Antimicrobial resistance' [3]. The Institute for Medical Microbiology and Hygiene, Austrian Agency for Health and Food Safety (AGES) in Graz was entrusted by the Austrian Ministry of Health with the tasks of a NRL for Staphylococcus aureus in 2007, and since then operates a sentinella system based on five hospitals. Our
Austrian data with ST398 and ST1 (t127) accounting for $10.8 \%$ of 250 clinical MRSA-isolates tested, fit well with those $9.7 \%$ reported from the other nine NRLs that reported data from clinical samples only [1].

The increasing proportion of ST398 clonal complex strains, termed 'LA-MRSA in isolates from human samples requires special attention. Much uncertainty remains about the origin and public health implications of LA-MRSA. AGES has started to survey the proportion of MRSA isolates from humans that were ST 398 in 2007 [4-6]. In the light of the increasing spread of LA-MRSA in Europe, Kinross et al. advocate that EU/EEA countries should consider periodically repeating this survey to monitor changes. They furthermore suggest that isolates from veterinary sources be included in such monitoring to systematically document potential reservoirs and transmission pathways to inform measures for prevention and control. We support such initiative and are pleased to contribute to this endeavour. 
Spa-Types, geographical origin and type of sample of LA-MRSA isolates $(n=18)$ and human isolates of ST1 (spa type 127) $(\mathrm{n}=9)$, Austrian National Reference Laboratory for coagulase-positive staphylococci, including Staphylococcus aureus, 2013

\begin{tabular}{|c|c|c|c|c|c|}
\hline $\begin{array}{l}\text { Sequence } \\
\text { Type }\end{array}$ & Spa-Type & No. of isolates & Primary laboratory/province & Sample & CT (cgMLST) \\
\hline \multirow[t]{5}{*}{398} & to11 & 14 & $\begin{array}{c}\text { Hospital A } \\
\text { Carinthia }(n=8) \\
\text { Hospital B } \\
\text { Lower Austria }(n=4) \\
\text { Hospital C } \\
\text { Vienna }(n=2)\end{array}$ & $\begin{array}{c}\text { Nose swab }(n=4) \\
\text { Urine }(n=1) \\
\text { Throat swab }(n=2) \\
\text { Perianal swab }(n=1) \\
\text { Wound swab }(n=5) \\
\text { Unknown }(n=1)\end{array}$ & $\begin{array}{c}46,1103,395,604 \\
98\end{array}$ \\
\hline & to34 & 1 & Hospital A & Wound swab & 1716 \\
\hline & $\mathrm{t} 108$ & 1 & Hospital B & Unknown & Not done \\
\hline & t571 & 1 & $\begin{array}{c}\text { Hospital D } \\
\text { Vienna }\end{array}$ & Wound swab & Not done \\
\hline & t3423 & 1 & Hospital A & Urine & Not done \\
\hline 1 & $\mathrm{t} 127$ & 9 & $\begin{array}{l}\text { Hospital A }(n=4) \\
\text { Hospital B }(n=4) \\
\text { Hospital C }(n=1)\end{array}$ & $\begin{array}{c}\text { Blood culture }(n=1) \\
\text { Wound swab }(n=4) \\
\text { Pleurocentesis fluid }(n=1) \\
\text { Bronchoalveolar lavage }(n=1) \\
\text { Unknown }(n=2)\end{array}$ & Not done \\
\hline
\end{tabular}

cgMLST = core genome multilocus sequence typing; CT = cluster type; LA-MRSA: Livestock-associated meticillin-resistant Staphylococcus aureus.

\section{Conflict of interest}

None declared.

\section{Authors' contributions}

WR, FA and BS wrote the draft manuscript. All authors corrected and approved the final version.

\section{References}

1. Kinross $P$, Petersen $A$, Skov $R$, Van Hauwermeiren $E$, Pantosti A, Laurent F, et al. The European Human LA-Mrsa Study Group. Livestock-associated meticillin-resistant Staphylococcus aureus (MRSA) among human MRSA isolates, European Union/European Economic Area countries, 2013. Euro Surveill. 2017;22(44):16-00696. . Available from: https:// doi.org/10.2807/1560-7917.ES.2017.22.44.16-00696 https:// doi.org/10.2807/1560-7917.ES.2017.22.44.16-00696 PMID: 29113628

2. Leopold SR, Goering RV, Witten A, Harmsen D, Mellmann A. Bacterial whole-genome sequencing revisited: portable, scalable, and standardized analysis for typing and detection of virulence and antibiotic resistance genes. I Clin Microbiol. 2014;52(7):2365-70. https://doi.org/10.1128/JCM.00262-14 PMID: 24759713

3. European Commission. Commission Implementing Decision of 8 August 2012 amending Decision 2002/253/EC laying down case definitions for reporting communicable diseases to the Community network under Decision No 2119/98/EC of the European Parliament and of the Council (2012/506/EU). Official Journal of the European Union. Luxembourg: Publications Office of the European Union; 27.9.2012:L262. Available from: http://eur-lex.europa.eu/LexUriServ/LexUriServ.do?uri=0J:L:2 012:262:0001:0057:EN:PDF
4. Springer B, Orendi U, Much P, Höger G, Ruppitsch W, Krziwanek K, et al. Methicillin-resistant Staphylococcus aureus: a new zoonotic agent? Wien Klin Wochenschr, 2009;121(3-4):86-90. https://doi.org/10.1007/s00508-008-1126-y PMID: 19280131

5. van Cleef BA, Monnet DL, Voss A, Krziwanek K, Allerberger F, Struelens $M$, et al. Livestock-associated methicillin-resistant Staphylococcus aureus in humans, Europe. Emerg Infect Dis. 2011;17(3):502-5. https://doi.org/10.3201/eid1703.101036 PMID: 21392444

6. Mayerhofer B, Stöger A, Pietzka AT, Fernandez HL, Prewein B, Sorschag $S$, et al. Improved protocol for rapid identification of certain spa types using high resolution melting curve analysis. PLoS One. 2015;10(3):e0116713. https://doi.org/10.1371/ journal.pone.0116713 PMID: 25768007

\section{License and copyright}

This is an open-access article distributed under the terms of the Creative Commons Attribution (CC BY 4.0) Licence. You may share and adapt the material, but must give appropriate credit to the source, provide a link to the licence, and indicate if changes were made.

This article is copyright of the authors, 2017. 